\title{
INTERNATIONAL JOURNAL OF ISLAMIC ECONOMICS AND FINANCE STUDIES
}

Uluslararasi İslam Ekonomisi ve Finansı Araştırmalan Dergisi

\author{
July 2017, \\ Vol:3, Issue:2 \\ e-ISSN: 2149-8407
}
Temmuz 2017,
Cilt:3, Sayı: 2
p-ISSN: 2149-8407

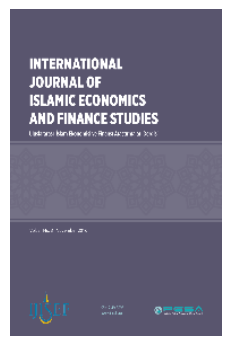

journal homepage: http://ijisef.org/

Gayrimenkul Sertifikalarının İlam İktisadı Perspektifinden
Değerlendirilmesi*

Doi: 10.25272/j.2149-8407.2017.3.2.06

\section{ÖZET}

Gayrimenkul projelerinin, herkesin ortak olabileceği küçük paylara bölünmesi ile oluşturulan yatırım aracı olarak tanımlanan gayrimenkul sertifikaları Türkiye'de ilk kez 1996 y1lında ihraç edildi. 1996 yilında yapilan ilk ihraçtan 17 yıl sonra gayrimenkul sertifikaları yeniden gündeme gelerek 2013 yılında SPK tarafindan yeni bir tebliğ hazırlandı. 2016 ve 2017 yılında bu tebliğde bazı

\section{Anahtar Kelimeler:}

Gayrimenkul Sertifikaları,

İslami Sermaye Piyasas,, Islami Finans

Keywords: Real Estate

Certificates, Islamic Capital

Market, Islamic Finance değişiklikler yapılarak 2017 yılının Nisan ayında gayrimenkul sertifikaları ikinci kez ihraç edilerek halka arz edildi. Bu ihracın 1996 yilında yapılan ihraçtan bazı önemli farkları vardır. Onlardan bir tanesi bu ürünün ortaklığa dayalı ve İslami esaslara uygun olduğunun lanse edilmesidir. İlgili açıklamalardan yeni bir sermaye piyasası ürünü olarak kabul edebileceğimiz gayrimenkul sertifikalarının İslami esaslara uygun olduğunun lanse edilmesi bu ürünün İslam iktisadı perspektifinden incelenmesini gerekli hale getirmektedir. Bu çalışmanın amacı, gayrimenkul sertifikalarını İslam iktisadı perspektifinden incelemektir. Bu kapsamda Türkiye için yeni olan bu ürünün nasıl işlediği açıklanarak ürüne ait inşaat projesinin yapımından ürünün ikinci el piyasada 
tedavülüne kadar olan süreçteki işlemler fikhi değerlendirmeye tabi tutulmuştur.

C 2017 PESA All rights reserved

\section{ABSTRACT}

Real Estate Certificates (REC), which are defined as investment instruments each of which represents small shares of real estate projects, were first issued in 1996 in Turkey. 17 years after the first issuance in 1996, REC came back on the agenda, and a new regulation was introduced by the Capital Markets Board of Turkey in 2013. Only after some changes were made in this regulation in 2016 and 2017, real estate certificates were issued for the second time in April 2017. This issuance has some important differences from the previous one. One of them is that issuing institutions introduce REC as an instrument based on partnership and adhering Islamic principles. This claim calls for careful discussion from the perspective of Islamic economics to see whether the real estate certificates, which can be regarded as a new capital market product, indeed meet Islamic principles. This paper first explains how this product works and then puts the transactions from the birth of the construction project upon which the certificates are created to the circulation of RECs in the secondary market under critical judicial (fiqh) evaluation.

* Bu makale 19-22 Mayıs tarihlerinde Uluslararası Politik Ekonomik ve Sosyal Araştırmalar Kongresinde sunulan bildirinin genişletilmiş halidir. 


\section{Giriş}

Gayrimenkul projelerinin, herkesin ortak olabileceği küçük paylara bölünmesi ile oluşturulan yatırım aracı olarak tanımlanan gayrimenkul sertifikaları Türkiye'de ilk kez 1995 yılında Sermaye Piyasası Kurulu tarafından çıarılan "Gayrimenkul Sertifikalarının Kurul Kaydına Alınmasına İlişkin Esaslar Tebliği (Seri: III, No: 19)” ile resmi düzenlemelere girdi. Türkiye Emlak Bankası A.Ş. tarafından 1996 yılında yapılan ilk ihraç, İstanbul'da Ataşehir konut projesini finanse etmek için gerçekleştirildi. 382 konut için ihraç edilen bu sertifikaların halka arz fiyatı 10TL olarak belirlendi ve İMKB tahvil ve bono piyasası bünyesinde Gayrimenkul sertifikaları pazarında işlem gördü (Vurgun, 2011, akt. Köroğlu, 2016). Bu sertifikaların borsadaki fiyatı piyasa koşullarında oluşmadı, ihraçcı Türkiye Emlak Bankası tarafından aylık olarak belirlendi (Akçay, 2006, s.41). Gayrimenkul sertifikalarına ait bu ilk ihraç, fiyat, getiri, vade ve şerefiye gibi unsurlardan dolayı çok fazla rağbet görmedi ve süreklilik kazanamadı (Köroğlu, 2016, s.30).

1996 yılında yapılan ilk ihraçtan 17 yıl sonra gayrimenkul sertifikaları yeniden gündeme gelerek 2013 yılında SPK tarafindan yeni bir tebliğ hazırlandı. 2016 ve 2017 yılında bu tebliğde bazı değişiklikler yapılarak 2017 yılının Nisan ayında gayrimenkul sertifikaları ikinci kez ihraç edilerek halka arz edildi. Bu ihracın 1996 yılında yapılan ihraçtan bazı önemli farkları vardır. Onlardan bir tanesi bu ürünün ortaklığa dayalı ve İslami esaslara uygun olduğunun lanse edilmesidir. İlgili açıllamalardan yeni bir sermaye piyasası ürünü olarak kabul edebileceğimiz gayrimenkul sertifikalarının İslami esaslara uygun olduğunun lanse edilmesi bu ürünün İslam iktisadı perspektifinden incelenmesini gerekli kılmaktadır.

Çalışmanın birinci bölümünde gayrimenkul sertifikalarının ne olduğu, nasıl işlediği açlklanmış ve gayrimenkul sertifikasına konu olan projenin tarafları arasındaki sözleşmelerde bulunan ve fikhi açıdan incelenmesi gereken bazı hükümlere dikkat çekilmiştir. İkinci bölümde gayrimenkul sertifikalarına ait muhtemel riskler açılanmış, üçüncü bölümde projenin taraflarının birbirleri ile olan hukuki ilişkileri ortaya konulmaya çalışlmış, böylece bu sertifikaların işleyişine ilişkin fikhi değerlendirme yapmak için bir zemin oluşturulmuştur. Dördüncü bölümde de bu zemin üzerine fikhi değerlendirme yapılmıştır.

\section{Gayrimenkul Sertifikasının Mahiyeti ve İşleyişi}

Gayrimenkul Sertifikası (GMS), gayrimenkul projelerine bireysel ve kurumsal yatırımcıların ortak olmalarına imkân veren bir yatırım aracı olarak tanımlanmaktadır ("Gayrimenkul sertifikası nedir", 2017). Bu sertifikalar bir şirketin, yeni başlayacak bir gayrimenkul projesindeki bağımsız bölümleri 
küçük paylara bölerek satmasına imkân vermektedir. Bu sertifikalardan yeterli sayıda satın alanlar tapu devri yoluyla bağımsız bölümün sahibi olmaktadır. Yeterli sayıda sertifika satın almayanlar ise sertifikaların değer artışından yararlanır. Zira GMS'lerin ikincil piyasası bulunmakta, bu sertifikalar Borsa İstanbul'da işlem görmektedir (Borsa İstanbul Gayrimenkul Sertifikaları, 2017 s.2). Sertifika sahipleri diledikleri takdirde aldıkları sertifikaları Borsa İstanbul üzerinden satabilmektedirler (Sertifikanın Amac1, 2017). Gayrimenkul sertifikası bir dairenin metrekare ile satı̧ı değildir. Bu sertifika TOKİ garantörlüğünde inşa edilen bir gayrimenkul projesine ortak olmayı ifade etmektedir. Bir başka deyişle gayrimenkul sertifikası sahipliği, projenin belli bir bölümüne alınan pay oranında yatırım ortağı olmak anlamına gelmektedir. Ayrıca sertifika sahiplerine projeden daire alma imkânı sağlanmıştır. Sertifika sahipleri, yeterli miktarda sertifikaya sahip olmaları halinde dilerlerse projeden daire alabilecekleri gibi, hisseleri oranında da yatırıma ortak olabilirler. Proje tamamlandığında elde edilen hasılattan kendi ortaklık payına düşen kısmı alabilirler ("Sertifikanın Amacı", 2017). Gayrimenkul sertifikası ile bir şirkete ortak olunmamakta, arsası belli, ruhsatı alınmış, inşaatı başlamış bir gayrimenkul projesine ortak olunmaktadır. Park Mavera 3 projesinde 1 sertifika ile projenin gayrimenkul sertifikasına konu kısmının 3.370.410'da birlik bir ortaklık payı elde edilmektedir ("Sertifika nasıl alınır", 2017). Aşağıdaki şekil yardımıyla gayrimenkul sertifikasının işleyişini daha iyi izah edebiliriz.

7 kat 28 daireden oluşan iki bloklu bir projenin tamamının gayrimenkul sertifikası ile satıldığını varsayalım. Proje bağımsız bölümler halinde küçük paylara ayrılır. Paylandırma esnasında dairelerin şerefiye farkları pay adetlerine yansitılır. Böylelikle konumuna, cephesine göre daha değerli olan dairelerin pay adedi daha fazla olur. Bu projede toplam pay 3 milyon adet olsun. A ve B blokta paylar aşağıdaki şekildeki gibi belirleniyor. 
Şekil 1: Bağımsız Bölümlerin Pay Adetleri (Örnek)

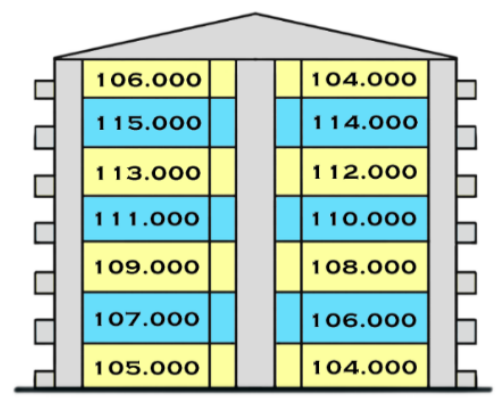

A BLOK

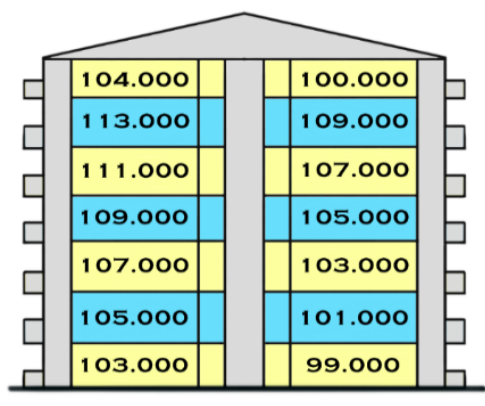

B BLOK

Kaynak: Sistem Nasıl Çalışıor? (2017).

Örneğin B blok zemin kattaki bir dairenin pay adedi 99 bin iken B blok orta kattaki bir dairenin pay adedi 111 bin olarak belirleniyor. Her bir pay için bir halka arz fiyatı belirleniyor. 1 pay değerini 5 lira olarak kabul edersek 3 milyon adet hissenin değeri 15 milyon TL'lik bir büyüklükle halka arz edilecektir. Bu işlemlerin ardından, hisseler borsada işlem görmeye başlar.

Borsada işlem gördüğü son güne kadar 7 dairenin yatırımcılar tarafından paylarının biriktirilmek suretiyle satın alındığını düşünürsek: 28 dairelik projedeki kalan $21 \mathrm{ev}$ açık artırma yöntemiyle satı̧̧a çıkarılacaktır. Kalan 21 evin pay adedi 2.248.000'dir. Açık artırma ile satı̧̧a çıkarılan evlerin aşağıdaki şekilde gösterilen fiyatlar ile satılırsa, evlerin satışından elde edilen hasılat 19.108.000 TL olacaktır. Evler satıldıktan sonra her pay başına düşen hasilat hesaplaniyor. 19.108.000 $T L \div 2.248 .000$ Pay $=8.5 T L$ olarak hisse fiyatı hesaplanmaktadır. Hisse sahiplerine pay başına 8,5 TL ödenecektir. Böylece halka arz aşamasında 5 TL'den pay satın alan yatırımcılar pay başına 3,5TL kar elde etmiş olurlar ("Sistem Nasıl Çalışıyor”, 2017). 
Şekil 2: Bağımsız Bölümlerin Satı̧̧ Fiyatları (Örnek)

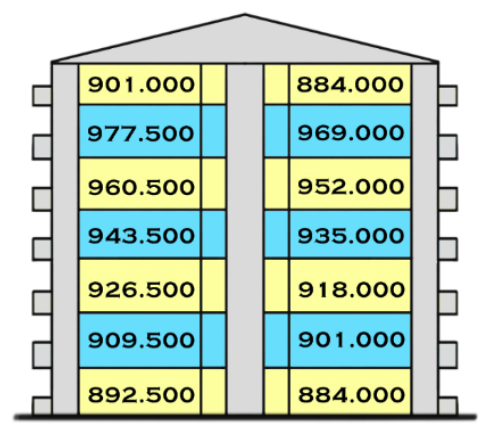

A BLOK

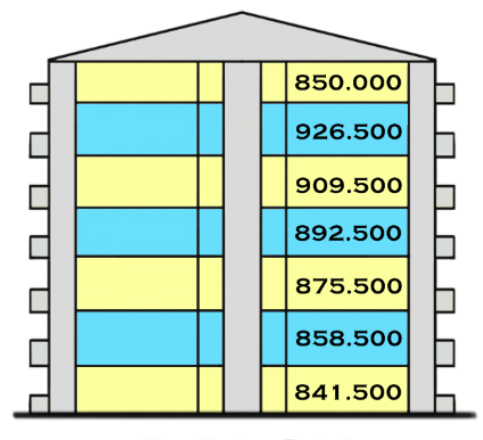

B BLOK

Kaynak: Sistem Nasıl Çalışıyor?. (2017).

Park Mavera 3 projesinde bir sertifikanın halka arz fiyatı 42,5 TL; toplamda ihraç edilen pay adedi ise 3.370.410 adet olmuştur. Buna göre, Park Mavera 3 projesinde 1 sertifika ile projenin gayrimenkul sertifikasına konu kısmının 3.370.410'da birine ortak olunmaktadır ("Sertifika nasıl alınır", 2017).

\subsection{Gayrimenkul Sertifikası Sahibinin Seçenekleri}

Sistemde gayrimenkul sertifikası sahibinin asli ve tali edim olmak üzere iki seçeneği bulunmaktadır.

\section{a) Asli Edim}

Yeterli sayıda sertifikaya sahip olanlar gayrimenkulün mülkiyetine hak kazanabilirler. Yeterli miktarda sertifikaya sahip olan bir yatırımcı proje tamamlanmadan önce asli edim talebinde bulunabilir. Proje bitmeden asli edim için başvuran yatırımcıların sertifikaları bloke edilerek talep ettikleri daire için gayrimenkul satış vaadi sözleşmesi imzalanır. Proje tamamlandıktan sonra ise, satı̧̧ vaadi sözleşmesi bulunanlar gayrimenkulün tapusunu alırlar. Aynı anda birden fazla kişi aynı daire için başvuruda bulunursa önce başvuran ile gayrimenkul satı̧s vaadi sözleşmesi yapılır. (Borsa İstanbul Gayrimenkul Sertifikalar1, 2017, s.3).

b) Tali Edim

Yeterli sayıda sertifikası olmayan veya bağımsız bölüm almak istemeyen yatırımcılar bağımsız bölümlerin açık artırma ile satılmasını bekler. Proje bitiminde asli edime konu olmayan bağımsız bölümler açık artırma usulü ile satılır. Satıştan elde edilen hasılat sertifika sahiplerinin payları oranında dağıtılır. Bu işleme tali edim denilir (TOKİ Gayrimenkul Sertifikasının 
İşleyişi, 2017). Asli edim talep etmeyen yatırımcılar proje bitiminden önce sertifikalarını borsada satarak nakde çevirebilirler. Bu anlamda gayrimenkul sertifikası, hızlı bir şekilde nakde çevrilebilen bir üründür (Borsa İstanbul Gayrimenkul Sertifikaları, 2017, s.3).

Şekil 3: Gayrimenkul Sertifikası Zaman Çizelgesi Örneği

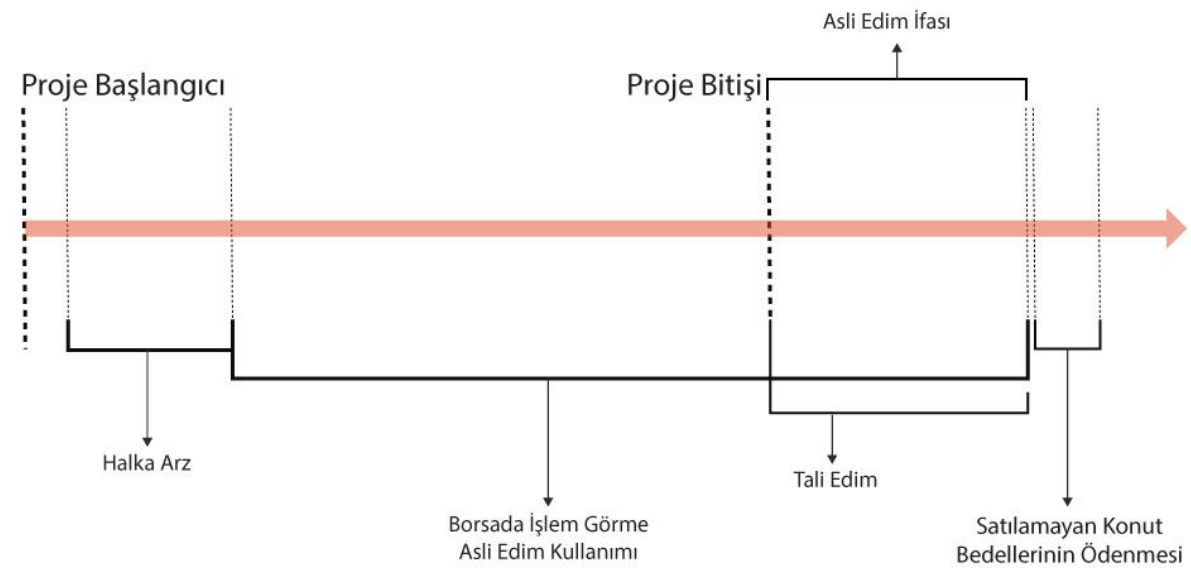

Kaynak: Borsa İstanbul Gayrimenkul Sertifikaları (2017, s.3)

Proje bitiminde tali edim talep eden sertifika sahipleri paylarına düşen hasılatı bağımsız bölümlerin tamamı satıldığında alırlar. Her bir bağımsız bölümün satışından elde edilen hasılat TOKİ tarafından özel bir hesapta toplanır. Bu hesapta toplanan fonların İslami esaslara uygun olarak nemalandırılacağı açıklanmış, bu fonların kira sertifikaları (sukuk) ve katılma hesaplarında değerlendirileceği ifade edilmiştir (Sermaye Piyasası Aracı Notu, 2017, s.13).

\subsection{Gayrimenkul Sertifikasında Yer Alan Çeşitli Hükümler}

Gayrimenkul sertifikasına konu olan Park Mavera 3 projesinin taraflarına ait gelir paylaşım sözleşmesi, sermaye piyasası aracı notu veya gayrimenkul sertifikası tebliğinde yer alan bazı hükümlere dikkat çekilmesinde fayda görülmektedir. Proje dokümanlarındaki maddeleri asli hükümler ve tali hükümler olarak ikiye ayırmak gerekirse bu bölümde bahsedeceğimiz hükümlerin tali hükümler kapsamına gireceğini düşünüyoruz. Yine de bu hükümlerin fikhi açıdan değerlendirilmesi önem arz etmektedir. Bu çalışmada tali hükümlere ilişkin fikhi bir değerlendirmeye yer verilmeyecek, sadece bu hükümlere dikkat çekmekle yetinilecektir.

- Proje süresi içinde yeterli sertifikaları toplayıp asli edim talep eden ve kendisiyle gayrimenkul satış vaadi sözleşmesi imzalanan yatırımcının sözleşme tarihinden itibaren 24 ay içerisinde sözleşmeden dönme hakkı vardır. 
Yatırımcının sözleşmeden dönmesi durumunda TOKİ adına yüklenici firma, yatırımcıdan sözleşme nedeniyle oluşan vergi, resim, harç ve benzeri yasal yükümlülükten doğan masraflar ile sözleşme tarihinden itibaren ilk üç ay için sözleşme bedelinin \%2'si, üç ile altı ay arası için \%4'ü, altı ile oniki ay arası için \%6'sı ve oniki ile yirmidört ay arası için \%8'i oranında tazminat ödenmesini isteyebilir (Sermaye Piyasası Aracı Notu, 2017, s.25).

- Projenin açıklanan bitiş tarihinde tamamlanmaması durumunda, kalan işlerin toplam işe oranı hesaplanır ve kalan işlere uygulanmak üzere her gecikme günü için bu oran ile arsa satı̧̧ karşıllı̆g Satış Toplam Gelir miktarı ${ }^{1}$ (AKSTG) çarpımının \%0,01 (Onbinde bir) oranında gecikme cezası uygulanır ve gecikme cezaları yatırımcıların hissesi oranına göre yatırımcılara ödenir (Sermaye Piyasası Aracı Notu, 2017, s.27).

- Arsa satışı karşılığında yüklenici şirket, TOKİye belirlenen 306 milyon TL’lik Arsa Satış Karşılığı İdare Payı Gelirini (AKİPG) aşağıdaki ödeme planına göre yapacaktır. Ödeme planındaki taksitlerin gecikmesi durumunda AKİPG'nin \%0.01'i oranında günlük gecikme cezası yükleniciden alınacaktır (Gelir Paylaşımı Sözleşmesi, 2017, md4, s.4).

Tablo 1: Yüklenicinin Ödeme Planı

\begin{tabular}{|c|c|c|c|}
\hline $\begin{array}{l}\text { Ödeme } \\
\text { No: }\end{array}$ & $\begin{array}{c}\text { Sözleşme İmza } \\
\text { Tarihinden İtibaren } \\
\text { Ödeme Günü (Taksit } \\
\text { Günü) }\end{array}$ & $\begin{array}{c}\text { Teklif Edilen Arsa } \\
\text { Satış Karş1lı̆ı İdare } \\
\text { Payı Geliri (AKİPG) } \\
\text { Ödeme Oranı (Taksit } \\
\text { Oranları) }\end{array}$ & $\begin{array}{c}\text { Ödeme Oranına Göre; } \\
\text { Arsa Satışı Karşılığı } \\
\text { İdare Payı (AKİPG) } \\
\text { Tutarı(Türk Lirası) }\end{array}$ \\
\hline 1 & 360'nc1 gün & $\% 10$ & $30.600 .000,00 \mathrm{TL}$ \\
\hline 2 & 540'nc1 gün & $\% 10$ & $30.600 .000,00 \mathrm{TL}$ \\
\hline 3 & 720'inci gün & $\% 20$ & 61.200.000,00 TL \\
\hline 4 & 900'üncü gün & $\% 20$ & 61.200.000,00 TL \\
\hline 5 & 1080'inci gün & $\% 20$ & $61.200 .000,00 \mathrm{TL}$ \\
\hline 6 & 1260'1nc1 gün & $\% 20$ & $61.200 .000,00 \mathrm{TL}$ \\
\hline 7 & TOPLAM & $\% 100$ & $306.000 .000,00 \mathrm{TL}$ \\
\hline
\end{tabular}

Kaynak: Gelir Paylaşımı Sözleşmesi (2017, md4, s.4).

- Yüklenici, idarenin uygun göreceği bir bankada veya özel finans kurumunda ayrı bir hesap açacak, bağımsız bölümlerin satışından elde edilecek gelirler tek bir hesapta toplanacaktır. Toplanan paraların Türk Lirası ve döviz cinsinden nemalandırılması TOKİ ve yüklenici tarafından yapılacaktır. (Gelir Paylaşımı Sözleşmesi, md7, s.7). Sözleşmede, elde edilecek hasılatın ayrı bir hesapta toplanması kararlaştırılmış ve bu paraların çeşitli şekillerde işletilerek nemalandırılacağı ifade edilmiştir. Fakat sözleşmede bu paraların İslami

\footnotetext{
${ }^{1} \mathrm{Bu}$ tutar Park Mavera 3 projesinde 1.020.000.000TL olarak belirlenmiştir.
} 
esaslara uygun olarak değerlendirilip değerlendirilmeyeceğine dair herhangi bir açıklama yapılmamıştır. TOKİ ile yüklenici arasındaki sözleşmede ifade edilmemesine karşın projenin halka arz izahnamesinde halktan toplanacak paraların İslami esaslara uygun olarak nemalandırılacağı açıklanmıştır (Sermaye Piyasası Aracı Notu, 2017, s. 13). Buradan hareketle ilk bakışta projenin halka arza konu olan yüzde 30'luk kısmı için toplanan paraların İslami yatırım araçlarında değerlendirileceği, yüzde 70'lik kısmı için ise böyle bir durumun söz konusu olmadığı anlaşlabilir. Fakat projedeki bütün bağımsız bölümlerin satışından elde edilecek hasılatın tek bir hesapta toplanacağı düşünülürse halka arza konu olan kısım için de hesapta biriken paraların İslami yatırım araçlarında nemalandırılacağı düşünülmektedir. Burada sözleşmeyi hazırlayanlar ya bu hükmü sözleşmeye eklemeyi gözden kaçırmış ya da lüzum görmemişlerdir.

- "Tali edim ifa süresi bitiş tarihi itibarıla satılamayan bağımsız bölümlerin olması durumunda, bu bağımsız bölümlere karşıllk gelen gayrimenkul sertifikalarının itfasına ilişkin olarak ihraççı tarafından yatırımcılara yapılacak ödemelerde, gayrimenkul sertifikalarının vade tarihinden önceki üç aylık dönemde borsada oluşan ağırlıklı ortalama fiyatların ortalaması esas alınır" (Gayrimenkul Sertifikaları Tebliği, 2013, md.8, f.3, b.e).

\section{Gayrimenkul Sertifikası ile İlgili Riskler}

Bir finansal ürün olarak gayrimenkul sertifikalarını etkileyebilecek bazı riskler bulunmaktadır. Bu riskler ise şu başlıklar altında incelenebilir:

Siyasi Riskler: Türkiye'de meydana gelebilecek ve ülke ekonomisini etkileyecek her türlü siyasi olay bu finansal ürün için de risk faktörüdür. Ülke ekonomisini olumsuz yönde etkileyecek olaylar dolaylı da olsa ilgili projenin maliyetini, projeye gelecek talebi ve dolayssıla fiyatları olumsuz yönde etkileyecektir (İhraç̧̧ı Bilgi Dökümanı, 2017, s. 6).

Yüklenici ile İlgili Riskler: Gayrimenkul sektörü likit olmayan bir yapıya sahip olduğundan yüklenicinin finansal yapısı diğer gayrimenkul projelerinin satımından elde edeceği gelire bağlı olabilir. Gayrimenkul sektöründe yaşanacak bir daralma yüklenicinin diğer projelerindeki gayrimenkulleri satamamasına ve likidite problemi yaşamasına neden olabilir. Bu durum yüklenicinin gayrimenkul sertifikasına konu olan projedeki yükümlülüklerini tam olarak, zamanında ve planlandığı şekilde getirememesine neden olabilir (İhraççı Bilgi Dökümanı, 2017, s. 7). 
Gayrimenkul Sektöründeki Riskler: Gayrimenkul sertifikasına konu olan projenin bulunduğu lokasyondaki gayrimenkul fiyatlarının proje sonunda beklenen fiyatlar düzeyinde oluşmaması durumunda söz konusu sertifikaların fiyatları beklenenin altında oluşabilir. Uzun bir dönemden beri konut fiyatları yükselişini devam ettirse de son yıllarda bu artış hızının yavaşladığ görülmektedir (TCMB Konut Fiyat Endeksi, 2017, s.3) Bunun sebebi muhtemelen piyasadaki arz ve talep dengesinin oluşmaya başlamasıdır. Projenin yapılacağı bölgede konut arzının artmasının kira ve satış fiyatlarının kademeli olarak azalmasına yol açabilme ihtimali de bulunmaktadır (İhraççı Bilgi Dökümanı, 2017, s. 8).

İhraçcı İle İlgili Riskler: İhraçcı ile ilgili riskleri mevzuattan kaynaklanan riskler, yönetsel ve operasyonel riskler ve şeffaflık ile ilgili riskler olmak üzere üç alt başlık halinde incelenmiştir (İhraççı Bilgi Dökümanı, 2017, s. 6-7):

a) Mevzuatsal Riskler: TOKI'nin faaliyetleri ile ilgili yasal mevzuatta meydana gelebilecek muhtemel değiş̧iklikler ihraççı TOKİ ve yüklenici şirketin mali yapısını, operasyonel yapısını ve finansal esnekliğini olumsuz yönde etkileyebilir. Ayrıca TOKİ tarafından hazırlanan imar planlarının 2985 sayılı kanun uyarınca bazı kurum ve kuruluşlarca onaylanması zorunludur. $\mathrm{Bu}$ onayla ilgili mevzuatın ve prosedürlerin değişmesi durumunda TOKİnin faaliyet hızı düşebilir.

b) Yönetimsel ve Operasyonel Riskler: TOKİ tarafından yapılan işler ihale ile yüklenici şirketlere verilmekte, bu şirketler de düzenlenen şartnamelere uygun olarak projeyi gerçekleştirmektedir. Yüklenici firmanın şartnameye uygun olarak projeyi gerçekleştirmemesi TOKİ'nin ek maliyetlere katlanmasına neden olabilir. Bu da TOKİ'nin bütçe yapısını olumsuz yönde etkileyebilir. Ayrıca, TOKİ'nin sermaye piyasası aracı ihraçları konusunda sınırlı tecrübesinin olması, sermaye piyasası ile ilgili mevzuatlardaki yükümlülükleri yerine getirme sırasında aksaklıklara neden olabilir.

c) Şeffaflık İle ilgili Riskler: Bir kamu kuruluşu olduğundan TOKİ'nin gelir ve giderleri halihazırda Sayıştay denetimine tabidir. TOKİnin finansal ve mali yapısına ilişkin denetimi Sayıştay yapmaktadır. TOKİ'nin herhangi bir ticari işletme gibi finansal tablolarının bulunmaması, finansal verilerinin ve faaliyetlerine ilişkin bilgilerin kamuya duyurulmaması nedeniyle TOKİ'nin finansal durumu yatırımcılar nezdinde tam olarak bilinmemektedir. Bir başka deyişle TOKİnin finansal durumu yeterince şeffaf değildir. Bu durum yatırımciların TOKİnin finansal durumunu bilmeden hareket etmesine, 
yükümlülüklerini yerine getirecek finansal yapısı olmayan bir kuruluşun projesini çok karlı bir proje olarak görerek yatırım yapmasına neden olabilir.

\section{Taraflar Arasındaki Hukuki İlişkiler}

TOKİ ile yüklenici firma arasında ve Park Mavera 3 ortaklığı ile sertifika arasındaki hukuki ilişkilerin mahiyetine değinmekte fayda vardır.

\subsection{TOKİ ile Yüklenici Arasındaki Hukuki İlişki}

TOKİ ile yüklenici arasında arsa satış karşılığı gelir paylaşımı sözleşmesi imzalanmıştır. Bu sözleşmede TOKİ arsa sahibi, yüklenici ise projenin yapımını üstlenen taraftır. Sözleşmede projeden elde edilecek gelir 1.020.000.000TL, TOKİ'nin payı ise gelirin yüzde 30'una tekabül eden 306.000.000TL olarak belirlenmiştir. Proje satı̧̧ geliri sözleşmede belirlenen tutardan daha yüksek olması halinde yeni tutarın yüzde 30'u TOKI'nin payı olacaktır. Fakat proje bitiminde elde edilen tutar sözleşmede belirlenen proje geliri tutarından daha düşük olursa TOKİ bundan etkilenmeyecek her halükarda 306.000.000TL'yi alacaktır (Gelir Paylaşımı Sözleşmesi, 2017, md1, s.2).

\section{Şekil 4: TOKİ ile Yüklenici Arasındaki Gelir Paylaşım Oranı}

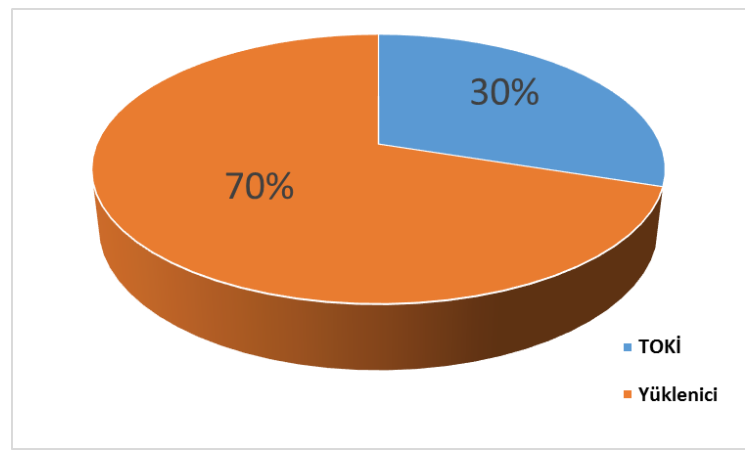

TOKİ ile yüklenici arasında yapılan gelir paylaşımı sözleşmesi incelendiğinde İslam hukuku açısından bir müşareke akdinden söz edebiliriz. Müşareke, iki veya daha fazla sayıda ortak tarafindan kurulan ve ortaklardan her birinin belirli miktarda sermaye koydukları bir ortaklık türüdür. Bu ortaklık türünde kar oranı anlaşma ile belirlenirken, zarar ortakların koydukları sermaye oranına göre belirlenir (AAOIFI, 2012:263). Ayrıca müşareke ortaklığında kazancın paylaşım esasları belirlenirken kar payının maktu bir miktar olarak değil, oran olarak belirlenmesi şarttır (Gözübenli, s.260). Yani kar paylaşımı, karın yüzde 20'si, yüzde 30'u şeklinde bir oran olarak belirlenmeli, karın 1 Milyon TL'si 
gibi maktu bir miktar olmamalıdır. Nitekim; ortaklıktan, önceden belirlenmiş maktu kar almak İslam hukukuna göre faiz sayılmaktadır (Döndüren, 2012:418). TOKİ ile yüklenici arasındaki gelir paylaşımı sözleşmesi incelendiğinde karın paylaşımının hem oran hem de maktu olarak belirlendiği görülmektedir. Sözleşmenin birinci maddesinde TOKİnin payı, gelirin yüzde 30'u olarak ifade edilmiş, bunun yanında 306.000.000TL olarak bir bedel de zikredilmiştir. Zikredilen maktu miktarın ilk bakışta tahmini bir bedel olduğu düşünülebilir. Fakat ileriki maddelerde TOKİnin gelirden alacağı payın hiçbir şekilde bu rakamdan aşağı düşmeyeceği açık bir şekilde ifade edilmiştir (Gelir Paylaşımı Sözleşmesi, 2017, md.3, s.2). Sözleşmede gelir paylaşımının hem miktar olarak belirlenmesi, hem de bu şartı kuvvetlendirecek şekilde, bu miktarın altına düşmeyeceği şartının eklenmesi akdi mahzurlu hale getirmektedir.

Müşarekede kural olarak sermayenin nakdi olması gerekmektedir. Ayni sermayenin kabul edilip edilmeyeceği ise mezhepler arasında ihtilaflıdır. Ebu Hanife ve Ahmed bin Hanbel müşareke tipi bir ortaklıkta sermayenin nakdi olmasının şart olduğunu, mal ve benzeri varlıkların sermaye olarak konulamayacağını söylerler. İmam Malik ise müşareke tipi bir ortaklıkta sermeyenin nakdi olmasının şart olmadığ kanaatindedir. İmam Şafi ise misli malların sermaye olarak konulabileceğini, kıyemi malların ise konulamayacağı görüşündedir (Usmani, 2004:25-26). AAOIFI (2012:264) ise ortakların anlaşmış olmalarına bağlı olarak gayrimenkul gibi nakdi olmayan varlıkların nakit değeri belirlendikten sonra sermaye olarak konulabileceği görüşündedir. Her ne kadar mezhep imamlarının çoğunluğunun görüşü; ortaklığa ayni sermaye konulamayacağ $\breve{1}_{1}$ yönünde olsa bile günümüzdeki ticari işlemlerin büyüklüğü ve çok daha karmaşık bir hale gelmiş olması düşünüldüğünde, AAOFI'nin temel aldığı görüş daha makul gözükmektedir. TOKI ile yüklenici arasında yapılan gelir paylaşımı sözleşmesi incelendiğinde TOKİ'nin kendi arsasını vererek ortaklığa ayni sermaye ile ortak olduğunu anlaşılmaktadır. AAOFI'nin görüşü benimsendiği takdirde TOKİ ile yüklenici arasındaki bu ortaklığa koyulan sermayelerin şekli ile ilgili bir problemin olmadığ1 söylenebilir.

TOKİ ile yüklenici arasında yapılan inşaat ve satış işine ait mutabakat metninin birinci maddesinde "yüklenicinin talep etmesi ve idarenin de uygun görmesi durumunda Arsa Satı̧̧ Karşllığı Satış Toplam Geliri (AKSTG)'nin en fazla \%30'u tutarında gayrimenkul sertifikası ihracı yapılabilir. Bu durumda satı̧̧ işlemleri satı̧̧ ofislerinin yanında gayrimenkul sertifikası işlemleri ile de yapılacaktır" (Mutabakat Metni, 2017, md.1) şeklinde bir ibare vardır. Bu 
ibareden hâlihazırda gerçekleştirilmiş olan gayrimenkul sertifikası ihracını, TOKİ'nin yüklenici adına yaptığını anlıyoruz. Zira aynı mutabakat metninin ikinci maddesinde şu ifadeler yer almaktadır:

"Gayrimenkul sertifikasının ihracı ve itfası aşamalarında ortaya çıkan veya oluşması muhtemel her türlü masraf ve maliyetler (SPK, Borsa İstanbul, MKK ve benzeri kurumlara ödenecek ücretler, aracillk komisyonu, tanıtım broşürü, ve diğer basım giderleri, her türlü organizasyon masrafları, medya tanıtımları, tüm danışmanlık hizmetleri ve benzeri masraflar ile bunlara ilişkin her türlü vergi, resim, harç ve benzeri masraflar) idarece yapilan yazilı tarihini müteakip 10 gün içerisinde yüklenici tarafindan ödenecektir." (Mutabakat Metni, md.2)

Park Mavera 3 projesinin başlangıçta TOKİ ile yüklenici arasında yapılmış bir müşareke ortaklığı olduğu, TOKİ'nin sadece projenin yapılacağı arsayı sermaye olarak koyduğu, bunun dışında herhangi bir maddi sorumluluğa girmediği anlaşılmaktadır. Ancak taraflar arasında yapılan sözleşme gereğince projenin yüzde 30'unun halka arz edilebileceği, TOKİnin ihraççı sıfatıyla halka arz işlemini yapacağı, fakat halka arz işleminde herhangi bir maliyete katlanmayacağı, bütün masrafların yüklenici tarafından ödeneceği anlaşılmaktadır.

\subsection{Park Mavera 3 Ortaklı̆g ile Sertifika Sahipleri Arasındaki Hukuki İlişki}

TOKİ ile yüklenici arasındaki hukuki ilişkinin bir müşareke ortaklığ1 olduğunu belirlemiştik. Projenin halka arz edilen yüzde 30'luk kısmını daha iyi izah etmek adına bu ortaklığa Park Mavera 3 (PMVR3) ortaklığı diyelim. Halka arz edilen bu kısım fikıhtaki istisna' akdinin kapsamına girmektedir. Gayrimenkul sertifikası ihraç ederek bu sertifikaları üçüncü kişilere satmak, üçüncü kişilerle bir istisna' akdi yapmak anlamına gelmektedir.

İstisna' akdi, “imal edilecek türden bir şeyin akdin teşekkülünden itibaren 1smarlanan kimse tarafindan malzemesi kendinden olmak üzere belli bir semen karşılığında nitelikleri belirlenmiş bir malın tesliminin üstlenildiği bir akittir" (Mustafa Ahmed ez-Zerka, VII/2[1412/1992], s.235 akt. Aktan, 1997, s.393). Günümüzde küçük atölyelerin imalatlarının yanı sıra her türlü proje ve taahhüt işleri istisna' akdi kapsamındadır (Aktan, 1997, s.395). Örneğin bir kişinin bir müteahhite bina yaptırması istisna' akdi kapsamına girmektedir.

Klasik fikıh literatüründe istisna' akdi ile ilgili hükümlere baktığımızda bu akdin iş tamamlanıncaya kadar taraflar arasında gayri lazım 
(bağlayıcı olmayan) bir akit olduğunun benimsendiğini görüyoruz. İş tamamlanıp ısmarlayan kişi malı gördüğünde akit bağlayıcı hale gelmekte ancak bu durumda da ismarlayan kişinin görme muhayyerliğinin olduğu kabul edilmektedir. Ismarlayan kişi eseri görüp beğenmezse kabul etmeyebilir. Klasik fikıh literatüründeki istina' ile ilgili hükümlerin günümüzde tekrar yorumlanmasına ihtiyacı duyulmuştur. Büyük inşaat projelerinin de istisna' akdinin kapsamına girdiği düşünüldüğünde özellikle istina' akdinin bağlayıcı olmadığ1 yönündeki hükümleri yeniden gözden geçirilmiştir. Böylece çağdaş hukukçular istisna' akdinin kurulduğu andan itibaren bağlayıcı olduğu ve ssmarlayana görme muhayyerliği şartının sağlanmasının makul olmadığı görüşünü benimsemişlerdir. Buna göre eser, başlangıçta belirlenen özelliklere uygun üretilmişse 1smarlayan kişi eseri kabul etmek zorundadır (Aktan, 1997, s.395).

Şekil 5: Taraflar Arasındaki F1khi İlişki

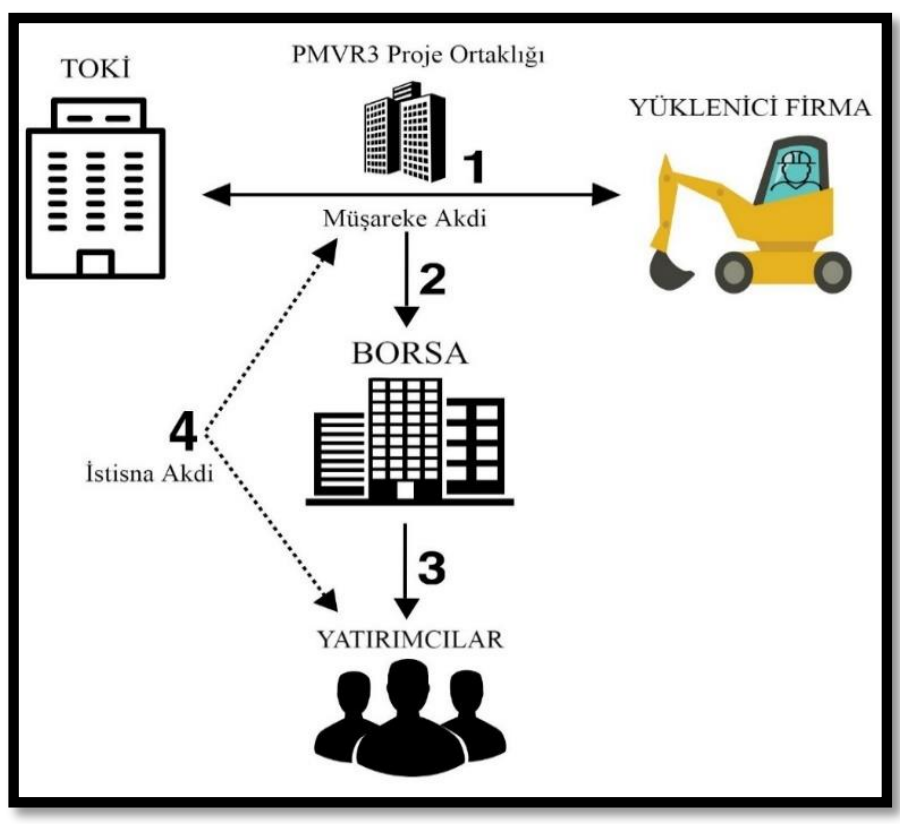

1-Toki ile yüklenici firma Park Mavera 3 projesini gerçekleştirmek üzere bir müşareke ortaklığı kurarlar. Bu ortaklıkta TOKİ arsayı verir. Yüklenici ise arsa üzerindeki inşaat projesini gerçekleştirmeyi taahhüt eder. 
2-TOKİ yüklenici adına gayrimenkul sertifikası ihraç ederek Borsa aracılığıyla bu sertifikaları satışa çıkarır. Bu sertifikalar Park Mavera 3 projesinin yüzde 30’luk kısmının paylara bölünmüş halini temsil eder.

3- Yatırımcılar borsa aracılığıyla sertifikaları satın alır. Böylece yatırımcılar, projenin yüzde 30'luk kısmındaki daireleri peşin bedelle satın almı̧ olurlar.

4- Bu satın alma işlemi sertifika sahipleri ile PMVR3 arasında yapılmış bir istisna akdidir. Ne kadar sertifika sahibi varsa o kadar kişinin ortaklaşa olarak PMVR3 ortaklığı ile istisna akdi yaptığı bir durum söz konusudur.

İstina' akdi ile ilgili bu kısa bilgileri verdikten sonra gayrimenkul sertifikası ile ilgili kısma yeniden geri dönelim. Gayrimenkul sertifikası alanlar 1smarlayan taraf, PMVR3 ise yüklenici taraftır. Tabiki burada gayrimenkul sertifikasına konu olan kısmın projenin tamamı değil sadece \%30’luk kısmıdır. Bu kısım da izahnamede ifade edildiği üzere B2, C2 ve D2 bloklarıdır. Bu bloklardaki daireler gayrimenkul sertifikasına konu olmuştur. Mutabakat metninin birinci maddesine göre "yüklenicinin talep etmesi ve idarenin de uygun görmesi durumunda Arsa Satı̧̧ Karş1lı̆̆ Satış Toplam Gelirinin (AKSTG) en fazla \%30'u tutarında gayrimenkul sertifikası ihracı yapılabilir. Bu durumda satı̧̧ işlemleri satı̧̧ ofislerinin yanında gayrimenkul sertifikası işlemleri ile de yapılacaktır" ifadesinden gayrimenkul sertifikasının bir satış işlemini ifade ettiği anlaşılmaktadır. Yani Park Mavera 3 ortaklı̆̆ı B2, C2 ve D2 bloklarındaki daireleri inşaat tamamlanmadan gayrimenkul sertifikası ile satmış olmaktadır. Bu satı̧̧ işlemini de biz istisna' akdi kapsamında değerlendiriyoruz. Fakat burada şu hususu ifade etmek gerekir: Bu satış işlemi her daireye bir kişi şeklinde değil, ne kadar gayrimenkul sertifikası sahibi varsa o kadar sayıda kişinin ortaklaşa aldıkları bir satış işlemini ifade etmektedir. Taraflar arasındaki hukuki ilişki Şekil 5'te açıklanmıştır. Buraya kadar fikhi olarak bir mahzur görülmemektedir. Yani birden fazla kişi bir araya gelerek bir müteahhide bina yaptırmak konusunda anlaşabilir ve sipariş verebilirler. Bina yapılıp teslim edildikten sonra o bina, siparişi veren kişilerin ortak malı olur. Fakat gayrimenkul sertifikasındaki mahzurlu nokta bu sertifikaların ikincil piyasada nominal fiyatından farklı fiyata alınıp satılabilmesidir. $\mathrm{Bu}$ hususu büyüteç altına alarak daha yakından inceleyelim. Bunu yapabilmek için gayrimenkul sertifikasının muamelat fikhında nereye denk geldiğine bakmamız gerekecektir. 


\section{Gayrimenkul Sertifikasının F1khi Mahiyeti}

Gayrimenkul sertifikalarının bir varlığın/projenin küçük paylara ayrılarak menkul kıymetleşleştirilmesini ifade etmesinden dolayı ilk olarak İslam Hukuku açısından menkul kıymetleştirme ile ilgili bazı noktalara temas etmek faydalı olacaktır. İslam Hukuku açısından menkul kıymetleştirilebilecek ürünler, İslam'ın alınıp-satılmasına, kullanılmasına müsaade ettiği mütekavvim mallardan olmalıdırlar. Menkul kıymetleştirme işleminde mülkiyetin tam olarak devri gerçekleşmediği durumlarda tarafların hakları ve sorumluluklarının sınırlarının belirlenmesinde problemler ve çatı̧̧malar ortaya çıkacaktır. Örneğin, üzerinde icare sukuk ihraç edilen varlığın kasıt-kusur olmaksızın zayi olması durumunda kiracı konumunda olan devletin veya kaynak kuruluşun anapara garantisi vermesi risk unsurunu ortadan kaldıracağından İslam'ın esaslarına uymayacaktır. Deprem sonucunda sukuka konu olan varlığın yıkılması halinde taraflar arasında uyuşmazlık çıkması muhtemeldir. Çünkü sukuka yatırım yapan kişilerin niyetleri riski minimum düzeye indirilmiş bir sertifikayı satın alarak gelir elde etmektir. Bu niyetin ve buna karşıllı oluşturulan sözleşmelerin durumu da aslında sözleşmeyi İslami esaslardan uzaklaştırmaktadır.

Menkul kıymetleştirmenin hedeflerinden biri de ikincil piyasa aracılığıyla bu sertifikalara likidite kazandırmasıdır. Fakat menkul kıymetleştirilmiş varlığa ait bu sertifikaları, ilk alıcısının başka taraflara ne

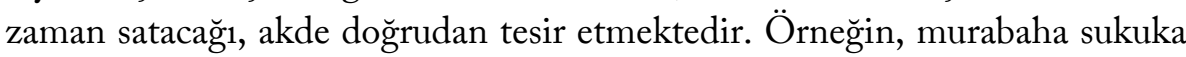
ait varlık karlı olarak satılan tarafa intikal etmesine kadar olan süreçte ikincil piyasada işlem görebilir. Fakat bu varlık, varlığa ihtiyacı olan tarafa geçtiği andan itibaren ise murabaha sukuk ikincil piyasada işlem göremez. Çünkü bu aşamadan sonra sukuk varlığ 1 değil, karlı satımdan elde edilen alacağı temsil etmektedir. Aynı şekilde selem sukuku, ikincil piyasada işlem göremez. Çünkü bu sukuk türü selem borcundaki payı temsil etmektedir. Mudarebe ve müşareke sukukta ise yatırıma başlandığı anda, yani sukuk bir varlığ1 temsil ettiği anda ikincil piyasa işlem görebilmektedir (AAOIFI, 2012:388).

Gayrimenkul sertifikalarını mevcut yapısı itibariyle bir sukuk/yatırım sertifikası olarak kabul edebiliriz. Sukukun tanımını incelediğimizde bu sertifikaların; "mevcut mal, menfaat, hizmet veya belirli bir proje veya özel bir yatırım faaliyeti halinde bulunan varlıklar üzerinde şayi ortak mülkiyeti ifade eder şekilde ve birbirine eşit değerde ihraç edilen sertifikalar" (AAOIFI, 2012:370) olarak tanımlandığını görüyoruz. Sukuk, İslâm hukukunun meşru gördüğü akitlere dayalı olarak ihraç edilir. Bu akitlerden bazıları mudarabe, müşareke, icare, selem ve istisna' akitleridir. Bu akitler İslam hukukuna göre 
meşru olduklarından dolayı bunlardan herhangi birisine dayalı olarak sukuk ihraç etmek de câiz olmaktadır (AAOIFI, 2012:388). Bu akitlere dayalı olarak ihraç edilen sukuk türlerini ayrı ayrı burada açıklamak bu çalışmanın maksadını aşacağından burada sadece gayrimenkul sertifikasının ilgili olduğu sukuk türünü açıklamanın yeterli olduğunu düşünüyoruz. İhraç edilen gayrimenkul sertifikasının özellikleri incelendiğinde bu sertifikaların istisna' akdine dayalı sukuk olduğunu kabul etmekteyiz.

AAOIFI (2012:372)'ye istisna' sukuk, “arz gelirlerinden elde edilen geliri istisna' akdine konu olan projeyi gerçekleştirmek ve/veya akit konusu malın imalatını sağlamak amacıyla birbirine eşit değerde ihraç edilen sertifikalardır." Bu sertifikaları satın alanlar istisna' konusu projenin/malın maliki olmaktadır. Park Mavera 3 ortaklığının ihraç etmiş olduğu gayrimenkul sertifikalarını bu tanımın içerisine yerleştirdiğimizde tam olarak uyduğunu görüyoruz. Park Mavera 3 projesi bir inşaat projesidir, gayrimenkul sertifikaları bu projeyi ${ }^{2}$ gerçekleştirmek için birbirine eşit değerde ihraç edilmiş sertifikalardır ve sertifikayı satın alanlar bu projenin malikidirler.

İstisna' akdine dayalı sukuku ihraç eden taraf, akit konusu malın imalatçı/satııısı (sâni') iken; yatırımcılar da imal edilmesi istenen malın alıcisıdırlar (müstasni'). Arz geliri ise, imal edilecek malın (masnû́) maliyetidir. Arz sonucunda sukuk satın alan yatırımcilar, menkulleştirilerek istisna' akdine konu malın maliki olurlar. Bu bakımdan söz konusu mal satıldığında bunun satı̧ bedelini veya eğer alt istisna (paralel istisna) işlemi gerçekleştirilmişse bu yolla satılan malın bedelini de hak ederler (AAOIFI, 2012:377).

Sukuk, mevcut mal ve menfaat halindeki varlıklarda pay sahipliğini temsil ediyorsa ikincil piyasalarda işlem görmesi ve tedavülü caiz olmaktadır. Zira bu sertifikaların ikincil piyasalarda işlem görmesi ve tedavülü ilgili varlıklara ait payların alınıp satılması anlamına gelmektedir. $\mathrm{Bu}$ varlıklar alınıp satılabildiğine göre bunlara ait payları temsil eden sukuk sertifikaları da alınıp sat1labilir(AAOIFI, 2012:388). Ancak bu varlıklar mevcut olmayan bir mal üzerinde pay sahipliğini temsil ediyorsa ikincil piyasada alınıp satılamaz.

İstisna akdine dayalı sukukun ikincil piyasada tedavülü konusunu da mevcut bir mal üzerinde pay sahipliğini temsil edip etmemesi bağlamında ele almak gereklidir. AAOIFI (2012: :385)'de yer alan hükme göre istisna' akdine dayalı olarak ihraç edilen sukuk, nakit para olmaktan çıkıp, proje konusu mal üzerindeki mülkiyeti temsil eder hale gelirse, ikincil piyasada işlem görebilir, tedavül edilebilir. Öyleyse, istina' sukuk ilgili projenin hangi aşamasında nakit

\footnotetext{
${ }^{2}$ Burada projeden kastettiğimiz Park Mavera Projesinin gayrimenkul sertifikasına konu olan $\mathrm{B} 2, \mathrm{C} 2$ ve D2 bloklarıdır.
} 
para olmaktan çıııp mevcut bir mal olarak kabul edilmektedir? Veyahut istisna' konusu projeye ait sertifikaların ikincil piyasada tedavülü için asgari şart nedir? Binanın tamamen bitmesi mi gerekir yoksa projeye ait inşaatın başlaması yeterli midir? İstanbul'da gerçekleştirilen GMS çalıştayında İslam hukukçularının genel kanaati, sertifikaların ikincil piyasada tedavülü için inşaata başlamanın yeterli olacağı yönünde olmuştur. (GMS Çalıştayı İstanbul, 2017). Bu durumda, bir bina yapım projesi için yüklenici sukuk ihraç etmişse bu binanın yapımına başlandığında sukuk sahipleri binanın maliki olurlar ve bu aşamadan sonra ellerindeki sukuku ikincil piyasada satabilirler. Bina yapımına başlamadan ise sukuk sahipleri ellerindeki sukuku ikincil piyasada satamaz. Çünkü bu durumda sukuk sahibinin elindeki bu sertifika bir borcu temsil etmektedir.

"İstisna sözleşmesine dayalı olarak ihraç edilen yatııım sertifikaları, nakit para olmaktan çıkıp sukuk sahiplerinin mülkü olan mevcut mallara (ayn) dönüştükten sonra ikincil piyasalarda işlem görmesi ve tedavülü mümkündür. $\mathrm{Bu}$ durumda yatırım sertifikaları mevcut varlıkları temsil ettiği için bunlar üzerinde tasarrufta bulunmak da câiz olmaktadır. (AAOIFI, 2012:389)"

AAOIFI'nin yukarıdaki kararı, alım satıma konu edilecek şeyin madum, yahut parasal nitelikli (deyn) olmaktan çıkıp ayni, somut mal haline gelmiş olmasını kurallaştırmaktadır. Buradan hareketle gayrimenkul sertifikalarında, projenin yapımına başlanmasıyla artık mübadeleye konu olan şey somut(ayn) mal haline gelmiş olduğu ve dolayısıyla ikincil piyasada tedavül etmesinde bir mahzur bulunmayacağı söylenebilir.

Yukarıda verdiğimiz bina yapım örneğini, istisna' sukuku için değil de müşareke sukuku için vermiş olsaydık, yani bina yapım projesi müşareke sukuk ihraç edilerek gerçekleştirilecek olsaydı, bu sertifikaların ikincil piyasalardaki satışı ile ilgili bina yapımına başlanma şartı aranmayacaktı. Çünkü bu durumda müşareke sukuk, projedeki ortaklık payını temsil edecek, bundan dolayı da ikincil piyasada satı̧ı tecviz edilecekti.

\section{Gayrimenkul Sertifikası ile Tasarrufa Dayalı Faizsiz Finansman Sistemi (TDFFS) Arasındaki Benzerlik ve Farklılıklar}

Gayrimenkul sertifikası ile TDFFS'yi karşılaştırdığımızda TDFFS'deki çekilişli yöntem ile GMS arasında bazı benzerlikler olduğu söylenebilir. TDFFS'deki çekilişli sistemde birçok kişi bir araya gelerek bir grup oluşturmakta ve toplanan fonlar her ay üyelerden birine verilerek o üyenin ev satın alması sağlanmaktadır. Evini alan üye diğer üyelere, aylık taksitine 
ilaveten kira yardımı adı altında ek ödeme yapmaktadır. TDFFS'nin mevcut haliyle, üyeler ile şirket arasındaki hukuki ilişkiler açısından bazı fikhi mahzurlar barındırdığı belirtilmektedir. Örneğin üyelerin birbirleri ile şirketin de üyelerle olan hukuki ilişkilerinin gerçekte var olan ile sözleşmede yazıldığ halinin birbiriyle örtüşmediği ifade edilmektedir. Mevcut sözleşmede sadece şirket ile üyeler arasındaki ilişki yer almaktadır. Bu ilişki de bir borç-alacak ilişkisidir. Yani belli bir süre üyeler şirkete borç vermekte daha sonra şirket üyelere borç vermektedir. Üyelerin birbirleri ile olan ilişkisi ise sözleşmede düzenlenmemiştir. En nihayetinde konuyla ilgili olarak Sakarya Üniversitesi'nde yapılan bir çalıştayda TDFFS'de varolan fikhi mahzurları gidermek anlamında getirilen önerilerden biri, sözleşmenin, üyelerin birbirleriyle ortak olarak evi aldığı ve evi teslim alan üyenin evdeki ortaklık payının taksitler ödendikçe arttığı bir şekilde düzenlenmesidir (Günay vd., 2017).

TDFFS'deki çekilişli sistemin fikhi zemininin daha düzgün olması için getirilen öneri, gayrimenkul sertifikasının halihazırdaki uygulamasına benzemektedir. TDFFS'ye getirilen öneri grup üyelerinin ortak olarak evleri satın almasıdır. GMS uygulamasında olan ise işte tam da budur. GMS birçok kişinin bir araya gelerek birlikte evleri satın almasıdır.

GMS ile TDFFS arasındaki en önemli fark ise TDFFS'yi gerçekten bir ev satın almak isteyenler kullanırken GMS'yi daha çok gayrimenkul projesinin değer artı̧ından kazanç sağlamak isteyen yatırımcılar tarafından tercih edilmektedir. Nitekim hâlihazırda GMS sahiplerinin yüzde 47,3'ünün yurtiçi kurumsal yatırımcı olması değer artış kazancının ön planda olduğunu göstermektedir (Halka Arz Sonuçları, 2017). Kanaatimizce bireysel yatırımcıların da büyük kısmı asli edimi değil tali edimi seçerek projenin değer artışından kazanç elde etmeyi amaçlamaktadır. Zira bireysel yatırımcıların da büyük kısmı İstanbul dışında yerleşiktir (GMS Çalıştayı İstanbul, 2017). Bireysel yatırımcıların büyük bir kısmının İstanbul dışında yaşıyor olması, bu yatırımcıların kullanım amacıyla ev satın almadıkları görüşünü desteklemektedir.

\section{Sonuç}

Gayrimenkul sertifikaları bir projenin kâr ve zararına ortak olmaktan çok, ortak olunarak bir gayrimenkul satın almayı ifade etmektedir. Örneğin 2, 5, 50 veyahut 100 kişinin bir araya gelerek birlikte bir daire satın almasıdır. Daha iyi izah etme maksadıyla şu örneği verebiliriz: A ve B gibi iki kişi anlaşıp bir daire satın almak isterler. Bir müteahhitten, temeli atılmış fakat henüz 
tamamlanmamış bir daireyi birlikte 150.000 TL'ye satın alırlar. Daire A ile B'nin ortak malıdır. Her ikisinin de payının eşit olduğunu ve 75.000 'er TL verdiklerini düşünelim. Henüz dairenin yapımı tamamlanmadan $A$, dairedeki payını 76.000TL'ye satarsa büyük oranda GMS'nin ikincil piyasadaki işleyişini gerçekleştirmiş olur. Aradaki tek fark A'nın, payını organize bir borsada satmamı̧̧ olmasıdır.

Eğer GMS'ler istisna' akdine dayalı olarak değil de müşareke akdine dayalı olarak ihraç edilmiş olsaydı, yani satışlar tamamlanıp elde edilen hasılat, sertifika sahipleri ile Park Mavera 3 ortaklığı ile paylaşılmış olsaydı, İslami finans mantığına daha uygun bir uygulama olurdu. Bu durumda sertifikanın ihraç fiyatı belirlenirken projenin maliyeti dikkate alınır ve paylar 42,5TL değil de daha düşük bir fiyata ihraç edilir, projenin tamamlanmasından sonra elde edilen gelirin tamamı GMS sahiplerine değil de GMS sahipleri ile PMVR3 ortaklığı arasında paylaştırılırmış olurdu. Bu durumda elbette GMS sahiplerinin elde edeceği kar miktarı daha az olacaktır fakat sertifikaları da daha düşük fiyata almış olacaklarını da gözardı etmemek gerekir. Ayrıca GMS’lerin müşareke akdine dayalı olarak ihraç edilmesi durumunda projenin riski taraflar arasında, yani hem GMS sahipleri hem de PMVR3 ortaklığ1 arasında paylaştırılmış olurdu. Zira mevcut durumda bütün risk GMS sahiplerinin üzerindedir. PMVR3 ortaklığ1 şimdiden dairelerini satmış ve paralarını almıştır. Dairelerin satılamaması veyahut düşük fiyatla satılması durumunda ortaya çıkan zarar tamamen GMS sahiplerinin üzerindedir. Her ne kadar dairelerin satılamaması durumunda TOKİ bu sertifikaları son 3 aylık ortalama piyasa fiyatı üzerinden alacağı garantisini vermiş olsa da piyasa fiyatının oldukça düşük olması durumunda sertifika sahiplerinin zararı telafi edilmemiş olmaktadır. Burada vurgulamak istediğimiz nokta GMS sahiplerinin zarar etmesi değil, kar-zarar paylaşımının olmamasıdır.

Borsa İstanbul'un GMS gibi yeni bir ürün üretmiş olması elbette ki İslami finansın gelişimi açısından olumlu bir adımdır. Fakat bu tür finansal ürünler üretilirken altlarında yatan dayanak sözleşmelerin fikhi olarak daha iyi incelenmesi gerekmektedir. Bu uygulamanın gerek Borsa İstanbul'un internet sitesinde gerek proje yüklenicisinin internet sitelerinde 'ortaklık' vurgusu yapılarak lanse edilmesine karşılık projenin yapımını üstlenen taraflar ile GMS sahiplerinin kar zarar paylaşımından söz etmek pek mümkün değildir.

GMS gibi bir uygulamanın borsa eliyle halka sunularak küçük yatırımcıların da büyük projelere yatırım yapabilme imkânının sağlanması son derece olumlu bir gelişmedir. GMS'de uygulanan aynı model kamunun büyük 
inşaat projelerinin finansmanında da uygulanabilir. Ancak uygulanacak modelin dayanak sözleşmeleri istisna' değil de mudarabe veya müşareke akitlerine dayalı olmalıdır. Zira bu akitler tam bir ortaklığı temsil etmekte, projenin kâr ve zararına her bir tarafın katılmasına imkân vermekte, bu da İslami finans mantığına daha uygun düşmektedir. Yapılması planlanan üçüncü hava limanı, Kanal İstanbul projesi ve Türkiye'nin 2023 vizyonuna ulaşma hedefi kapsamındaki daha pek çok proje bu tür sertifikalar ihraç edilerek finanse edilebilir ve halkın bu tür büyük projelere gerçek anlamda ortak olması sağlanabilir. Aynı şekilde borsada işlem görmesi sağlanarak bu sertifikalara likidite kazandırılabilir. Borsa İstanbul'un bu tür ortaklığa dayalı sertifikaların ihracında aktif rol oynaması, İslami finansal ürünlerin gelişmesine ve başarılı olmasına büyük katkı sağlayacaktır.

Bu çalı̧̧mada Türkiye için yeni sayılabilecek bir sermaye piyasası ürünü olan Gayrimenkul sertifikalarının ne olduğu ve nasıl işlediği açıklanarak taraflar arasındaki sözleşmeler genel hatlarıyla fikhi değerlendirmeye tabi tutulmuştur. Makalenin maksadını aşacağından, sözleşmelerdeki tüm maddeler ayrıntılı olarak fikhi değerlendirmeye tabi tutulmamıştır. İleriki çalışmalarda bu sözleşmelerin ayrıntılı olarak incelenmesi ve fikhen mahzurlu noktaların ortaya konulması faydalı olacaktır. 


\section{Kaynakça}

AAOIFI, (2012). Faizsiz Bankacilik Standartları (Shari'a StandardsAAOIFI). İstanbul: Türkiye Katılım Bankaları Birliği.

Akçay, B. (2006). Avrupa Birliği Finansal Entegrasyon Sürecinde İpotekli Piyasalar: Aday Ülke Statüsünde Olan Türkiye'ye Bir Bakış. Ankara Avrupa Çalışmaları Dergisi, 6(1), 19-47.

Aktan, Hamza. (1997). İstisna'. İslam Ansiklopedisi (Diyanet), 22.

Döndüren, H. (2012). Delilleriyle ticaret ve iktisat ilmihali.

Gayrimenkul Sertifikaları Gayrimenkul Projelerine Yatırım Aracı. (2017). Erişim adresi: http://www.borsaistanbul.com/docs/defaultsource/duyuru-dosyalari/gayrimenkul-sertifikalaribrosuru.pdf?sfvrsn=5. Erişim tarihi: 08.05.2017

Gayrimenkul Sertifikaları Gayrimenkul Projelerine Yatırım Aracı. (2017). Erişim adresi: http://www.borsaistanbul.com/docs/defaultsource/duyuru-dosyalari/gayrimenkul-sertifikalaribrosuru.pdf?sfvrsn=5. Erişim tarihi: 08.05.2017

Gayrimenkul Sertifikaları Tebliği (2013,5 Temmuz). Resmi Gazete (Say1: 28698). Erişim

Adresi: http://www.resmigazete.gov.tr/main.aspx?home=http://www.resmigaz ete.gov.tr/eskiler/2013/07/20130705.htm\&main=http://www.resmiga zete.gov.tr/eskiler/2013/07/20130705.htm

Gayrimenkul sertifikası nedir?. (2017). Erişim adresi: http://gayrimenkuldesertifika.com/sorular/gayrimenkul-sertifikasinedir. Erişim tarihi: 08.05.2017

Gayrimenkul sertifikası nedir?. (2017). Erişim adresi: http://gayrimenkuldesertifika.com/sorular/gayrimenkul-sertifikasinedir. Erişim tarihi: 08.05.2017

Gayrimenkul Sertifikasının İşleyişi. (2017). Erişim Adresi: http://www.toki.gov.tr/gayrimenkul-sertifikasinin-isleyisi. Erişim tarihi: 08.05.2017

Gayrimenkul Sertifikasının İşleyişi. (2017). Erişim Adresi: http://www.toki.gov.tr/gayrimenkul-sertifikasinin-isleyisi. Erişim tarihi: 08.05.2017

Gelir Paylaşımı Sözleşmesi. (2017). Erişim Adresi: http://www.toki.gov.tr/haber/gayrimenkul-sertifikasi-ihrac-duyurusu. Erişim tarihi: 08.05.2017 
Gelir Paylaşımı Sözleşmesi. (2017). Erişim Adresi: http://www.toki.gov.tr/haber/gayrimenkul-sertifikasi-ihrac-duyurusu. Erişim tarihi: 08.05.2017

Gözübenli, B. (1997). İnan. İslam Ansiklopedisi (Diyanet), 22.

Günay, H.M., Görmüş, Ş., Koç, İ., Çekin, Ö. (Ed.). (2017). Tasarrufa Dayalı Faizsiz Finans Sistemi. (Basılmamı̧ Kitap)

Halka Arz Sonuçları. (2017). http://www.ntv.com.tr/ekonomi/turkiyeninilk-gayrimenkul-sertifikasi-halka-arzsonuclari,tcRDIdCZHUWgICsA4H6woA. Erişim tarihi: 30.05.2017

İhraççı Bilgi Dökümanı. (2017). Erişim Adresi: http://www.toki.gov.tr/haber/gayrimenkul-sertifikasi-ihrac-duyurusu. Erişim tarihi: 08.05.2017

İhraççı Bilgi Dökümanı. (2017). Erişim Adresi: http://www.toki.gov.tr/haber/gayrimenkul-sertifikasi-ihrac-duyurusu. Erişim tarihi: 08.05.2017

İslami Finans, Gayrimenkul Sektörü ve Yatırımcı Perspektifinden Gayrimenkul Sertifikaları. (2017). https://www.youtube.com/watch?v=3WY1QZeZ26s. Erişim Tarihi: 31.05.2017

Köroğlu, A. (2016). Gayrimenkul Sertifikası Modeli Ve Türkiye'de Uygulanabilirliği. Gazi İktisat ve İşletme Dergisi, 2(1).

Mutabakat Metni. (2017). Erişim Adresi: http://www.toki.gov.tr/haber/gayrimenkul-sertifikasi-ihrac-duyurusu. Erişim tarihi: 08.05.2017

Mutabakat Metni. (2017). Erişim Adresi: http://www.toki.gov.tr/haber/gayrimenkul-sertifikasi-ihrac-duyurusu. Erişim tarihi: 08.05.2017

Sermaye Piyasası Aracı Notu. (2017). Erişim Adresi: http://www.toki.gov.tr/haber/gayrimenkul-sertifikasi-ihrac-duyurusu. Erişim tarihi: 08.05.2017

Sermaye Piyasası Aracı Notu. (2017). Erişim Adresi: http://www.toki.gov.tr/haber/gayrimenkul-sertifikasi-ihrac-duyurusu. Erişim tarihi: 08.05.2017

Sertifika nedir nasıl alınır?. (t.y). Erişim Adresi: http://gayrimenkuldesertifika.com/sertifika-nedir-nasil-alinir. Erişim tarihi: 08.05.2017 
Sertifika nedir nasıl alınır?. (t.y). Erişim Adresi: http://gayrimenkuldesertifika.com/sertifika-nedir-nasil-alinir. Erişim tarihi: 08.05.2017

Sertifikanın amacı nedir?. (2017). Erişim Adresi: http://gayrimenkuldesertifika.com/sorular/sertifikanin-amaci-nedirmetrekare-ile-daire-satmak-mi. Erişim tarihi: 08.05.2017

Sertifikanın amacı nedir?. (2017). Erişim Adresi: http://gayrimenkuldesertifika.com/sorular/sertifikanin-amaci-nedirmetrekare-ile-daire-satmak-mi. Erişim tarihi: 08.05.2017

Sistem Nasil Çalışıyor?. (2017). https://www.youtube.com/watch?v=fpgOD0im0IU\&list=PLi79jKVm TucTVZ6yl8m7L2rwmJeJEKleG\&index=3 [video]. Erişim tarihi: 08.05.2017

Sistem Nasıl Çalı̧̧ıor?. (2017). Erişim Adresi: https://www.youtube.com/watch?v=fpgOD0im0IU\&list=PLi79jKVm TucTVZ6yl8m7L2rwmJeJEKleG\&index=3 [video]. Erişim tarihi: 08.05.2017

Usmani, T. (2004). An introduction to Islamic finance. Retrieved from https://www.google.com/books?hl=tr\&lr=\&id=0aDStXqUAgC\&oi=fnd \&pg=PA1\&dq=usmani + an + intoduction + to + islami $+\&$ ots=0lckRZRs38\&sig=EBumlmqWwqK4pFqUyY_ThsfbtSs

Konut Fiyat Endeksi. (2017). TCMB. Erişim Adresi: http:/www.tcmb.gov.tr/wps/wcm/connect/8c36f435-ef59-47e6-af029f20b9e613e7/KFE-

KFE.pdf?MOD=AJPERES\&CACHEID=ROOTWORKSPACE8c 36f435-ef59-47e6-af02-9f20b9e613e7. Erişim Tarihi: 13.06.2017 